V.A. Yarovenko, P.S. Chernikov, E.I. Zaritskaya, A.N. Schumylo

\title{
CONTROL OF ELECTRIC SHIPS' PROPULSION MOTORS WHEN MOVING ON CURVILINEAR TRAJECTORY
}

Purpose. The aim of the work is to search for the optimal control of the electric ships' propeller motors (PM) while moving on curvilinear trajectory. The indices characterizing the vessel were selected as the criteria of optimality. Methodology. Optimal control laws of PM providing electric ships' best maneuverability can be found by joint consideration of the electric propelling plant (EPP), propellers and hull. Results. A method of calculating the transient regimes of the electric ships' propulsion complexes during maneuver has been developed. A new method of forming the PM control laws is proposed. The nature of the target functions is revealed and a method of optimizing the parameters of control signals is developed. Optimization calculations have been carried out and the optimal control of the electric ships' propeller motors when moving along curvilinear trajectory has been found. Optimization has been carried out by the criterion of minimum energy consumption and by the criterion of minimum ship's distance. The optimization efficiency is illustrated. Scientific novelty. The method of searching for the optimal control laws is constructed according to the system principle, which allows optimizing the control of the propulsion motors by the final result. Practical value. The proposed recommendations can be used in the design of electric propelling plants and in their operation. References 10, tables 3, figures 6.

Key words: electric ships' propulsion motors, control on maneuvers, optimal control during curvilinear motion, optimization method.

Метою роботи є пошук оптимального управління гребними електродвигунами (ГЕД) електроходів при русі по криволінійній траєкторії. В якості критеріїв оптимальності обрані показники, цчо характеризують судно. Методика. Оптимальні закони управління ГЕД, щоб забезпечити найкращі маневрені характеристики електроходів, можуть бути знайдені при спільному розгляді гребної електроенергетичної установки, гребних гвинтів $і$ корпусу судна. Результати. Розроблено метод розрахунку перехідних режсимв пропульсивних комплексів електроходів при маневруванні на криволінійній траєкторії. Запропоновано новий спосіб формування законів управління ГЕД. Виявлено характер цільових функцій і розроблений метод оптимізації параметрів сигналів управління. Проведено оптимізаційні розрахунки і знайдено оптимальне управління гребними електродвигунами електроходів при русі по криволінійній траєкторії. Оптимізація проведена за критерієм мінімуму витрат енергї $i$ за критерієм мінімуму вибігу судна. Проілюстрована ефективність оптимізації. Наукова новизна. Метод пошуку оптимальних законів управління побудований за системним принципом, що дозволяс оптимізувати управління гребними електродвигунами за кінцевим результатом. Практична значимість. Запропоновані рекомендації можуть використовуватися $і$ при проектуванні гребних електроенергетичних установок і при ̈̈х експлуатації. Бібл. 10, табл. 3, рис. 6.

Ключові слова: гребні електродвигуни електроходів, управління на маневрах, оптимальне управління при криволінійному русі, метод оптимізації.

Целью работы является поиск оптимального управления гребными электродвигателями (ГЭД) электроходов при движении по криволинейной траектории. В качестве критериев оптимальности выбраны показатели, характеризующие судно. Методика. Оптимальные законы управления ГЭД, обеспечивающие наилучшие маневренные характеристики электроходов, могут быть найдены при совместном рассмотрении гребной электроэнергетической установки, гребных винтов и корпуса судна. Результаты. Разработан метод расчета переходных режсимов пропульсивных комплексов электроходов при маневрировании на криволинейной траектории. Предложен новый способ формирования законов управления ГЭД. Выявлен характер целевых функций и разработан метод оптимизации параметров сигналов управления. Проведены оптимизационные расчеты и найдено оптимальное управление гребными электродвигателями электроходов при движении по криволинейной траектории. Оптимизация проведена по критерию минимума расхода энергии и по критерию минимума выбега судна. Проиллюстрирована эффективность оптимизации. Научная новизна. Метод поиска оптимальных законов управления построен по системному принципу, что позволяет оптимизировать управление гребными электродвигателями по конечному результату. Практическая значимость. Предложенные рекомендации могут использоваться и при проектировании гребных электроэнергетических установок и при их эксплуатации. Библ. 10, табл. 3, рис. 6.

Ключевые слова: гребные электродвигатели электроходов, управление на маневрах, оптимальное управление при криволинейном движении, метод оптимизации.

Introduction. The presence in electric ships, in addition to the steering gear, of several powerful, dynamic and overload-resistant propulsion electric motors (PM) allows to achieve high maneuverability of these ships. With the joint maneuvering of the rudder and propellers, the ship's turnability improves, the degree of safety of maneuvering operations increases [1]. At the same time, this significantly changes the load on the propulsion motors and on the entire propulsion power plant as a whole.
The curvilinear trajectory of the ship's movement, its yaw, the change in the conditions of interaction of propellers, rudder and ship's hull significantly affects the forces and moments of forces acting on the ship's hull during its curvilinear unsteady motion [2, 3]. The forces and moments developed by the propellers are subject to an even greater change - the useful stop and the moment of resistance of the water to the rotation of the propeller and, accordingly, the moment of resistance to the

(c) V.A. Yarovenko, P.S. Chernikov, E.I. Zaritskaya, A.N. Schumylo 
propeller motor. Their values change as a result of the changing bevel angle of the water flow and changes in the speed of the vessel. Thrust, drag moment and lateral force values for inner and outer propellers (in relation to the center of circulation) differ significantly from each other [4].

In Fig. 1, plans for the speeds of two propellers are built for the curvilinear movement of the vessel, where: $v$ is the linear speed of movement of the center of gravity of the vessel; $\beta$ is the drift angle; $\alpha_{B e v L}$ and $\alpha_{B e v R}$ are the bevel angles of the water flow incident on the left and right propellers, respectively; $u_{L}$ and $u_{R}$ are the transverse components of the speed of movement of the left and right propellers; $v_{L}$ and $v_{R}$ are the speeds of the left and right propellers.

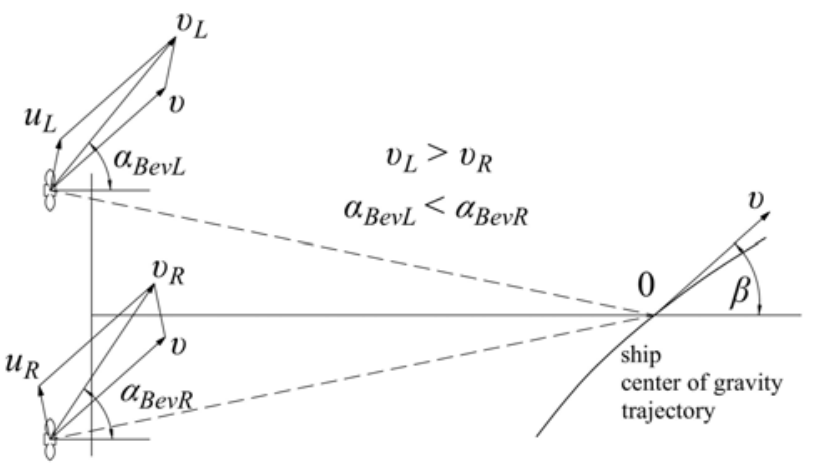

Fig. 1. Propeller speed plan for curvilinear movement

Figure 1 shows that the inner propeller operates in a flow with a larger bevel angle, and the outer one - with a smaller one. This affects the dynamic characteristics of the propellers and the moment of resistance to the external and internal PM. The loads on them turn out to be different, which can lead to the activation of the protection systems of the more loaded propeller motor and, ultimately, to the failure to perform the maneuver.

All this must be taken into account when generating control signals for propulsion motors. They must be such as to ensure, on the one hand, the best controllability of the electric ship, and on the other hand, the operation of all components of the propulsion electric propelling plant (EPP) in permissible modes.

The state of the issue under study. The control of the frequency-controlled propulsion motors of the EPP of the electric ship is carried out by generating two signals [5-7]:

- relative frequency of the supply voltage

$$
\alpha=\frac{f}{f_{N}} ;
$$

- relative supply voltage

$$
\gamma=\frac{U}{U_{N}} .
$$

The relationship between the relative voltage $\gamma$ and the relative frequency $\alpha$ is called the frequency control law. In $[8,9]$, it is shown that for frequency-controlled propeller motors, the classical (proportional) control law is not effective, since it was obtained in relation to the performance indicators of electric motors. In propelling electric power plants for control of propulsion electric motors during maneuvers, it is necessary to have such laws that will ensure the best maneuvering properties of electric ships. The performance indicators of the EPP, in this case, should not go beyond the permissible limits.

In [8], an approach to solving the problems of finding optimal control laws for propeller electric motors is described. A method for generating control signals based on a systemic principle is proposed. The procedure for optimization calculations has been developed. The optimal parameters of the control laws are found for maneuvering on a straight course. The efficiency of the transition to the recommended control laws is illustrated by a comparative analysis of the results of performing maneuverable operations with control according to classical laws and according to the found optimal relations between $\gamma$ and $\alpha$.

A change in the nature of maneuver, simultaneous control of both the propulsion electric motors and the rudder, the need to take into account both the maneuverability indicators of the electric ship and the performance indicators of the propulsion electric power plant will undoubtedly affect the laws of frequency control.

The goal of this research is the search for the optimal laws of control of the propelling electric motors of electric ships moving along a curvilinear trajectory, with joint maneuvering of the PM and the rudder.

Method for solving the problem. To achieve the goal, it is necessary to develop a mathematical model of the transient modes of operation of the propulsive complex of an electric ship when moving along a curvilinear trajectory, to form an objective function and to find the optimal laws of control of the PM during maneuvers.

An enlarged block diagram of one power circuit of the propulsive complex of an electric ship without taking into account the mutual connections is shown in Fig. 2.

Each of its «power» circuits includes: heat engine $D$, synchronous generator $-G$, frequency converter of electricity $-S E$, induction propeller motor $-M$, heat engine speed regulator - $D R$, synchronous generator voltage regulator $-G E$, propeller - $P$. The propulsion system also includes rudder $-R$ and ship's hull. The main parameters of the complex, control signals and feedback signals: $\omega_{D}$ and $P_{D}-$ angular speed of rotation and power of heat engines; $U_{G}$ and $I_{G}$ - voltage and current at the generator output; $U_{M}$ and $I_{M}$ - voltage and current of propelling motors; $M_{M}$ and $\omega_{M}$ - torque and angular velocity of rotation of PM (and propellers).

On the basis of the block diagram, a mathematical model and codes for calculating transient modes of operation of the propulsion complex during maneuvers were developed [10]. Generalized dimensionless parameters of the complex are found. Changes in the values of these parameters determine the behaviour of electric ships and affect the numerical values of the quality indicators of maneuvering. 


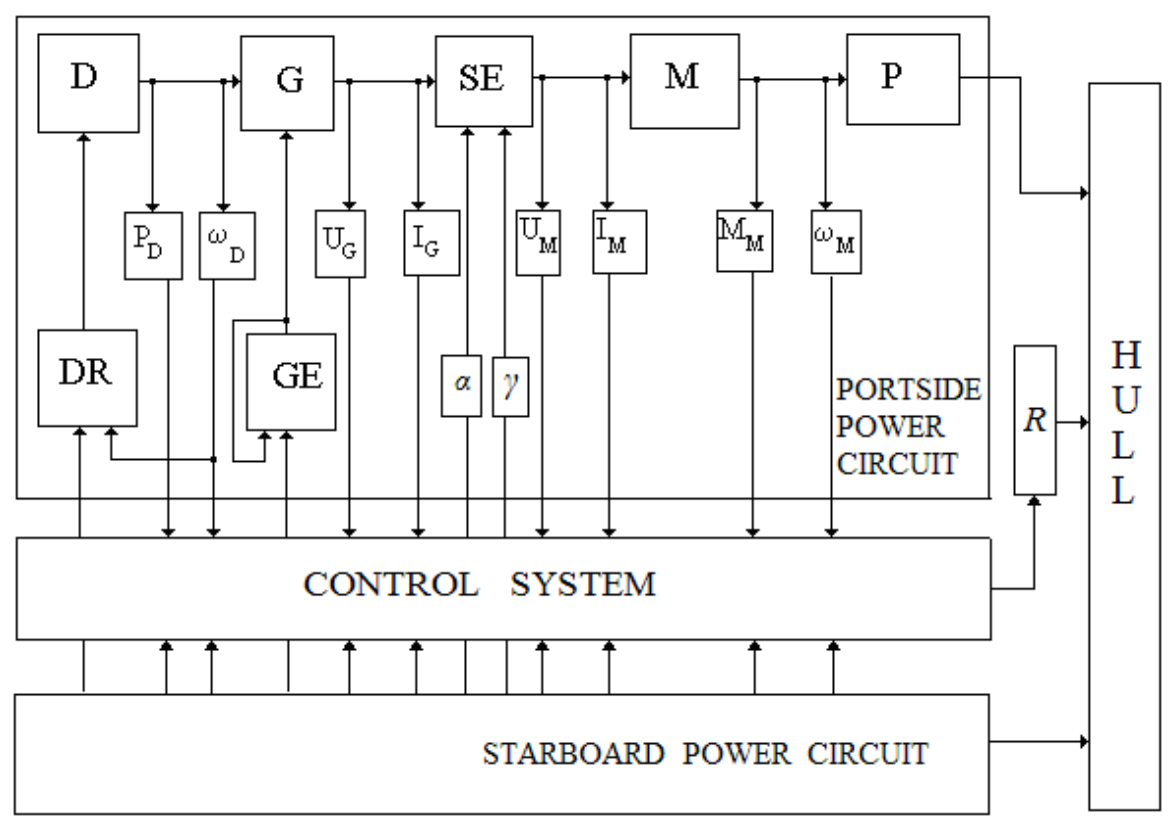

Fig. 2. Block diagram of one power circuit of the propulsive complex of the electric ship

As an example, in Fig. 3, the results of calculations of the current values of the main operating parameters of the components of the propulsion complex are shown when the electric ship is performing the maneuver «acceleration of the propulsion power plant - the ship's exit to a curvilinear trajectory (circulation)».
Results are given in relative time

$$
T=v_{0} t / L,
$$

where: $v_{0}$ is the ship's speed in the steady-state (basic) mode; $L$ is the length of the vessel; $t$ is the current time.

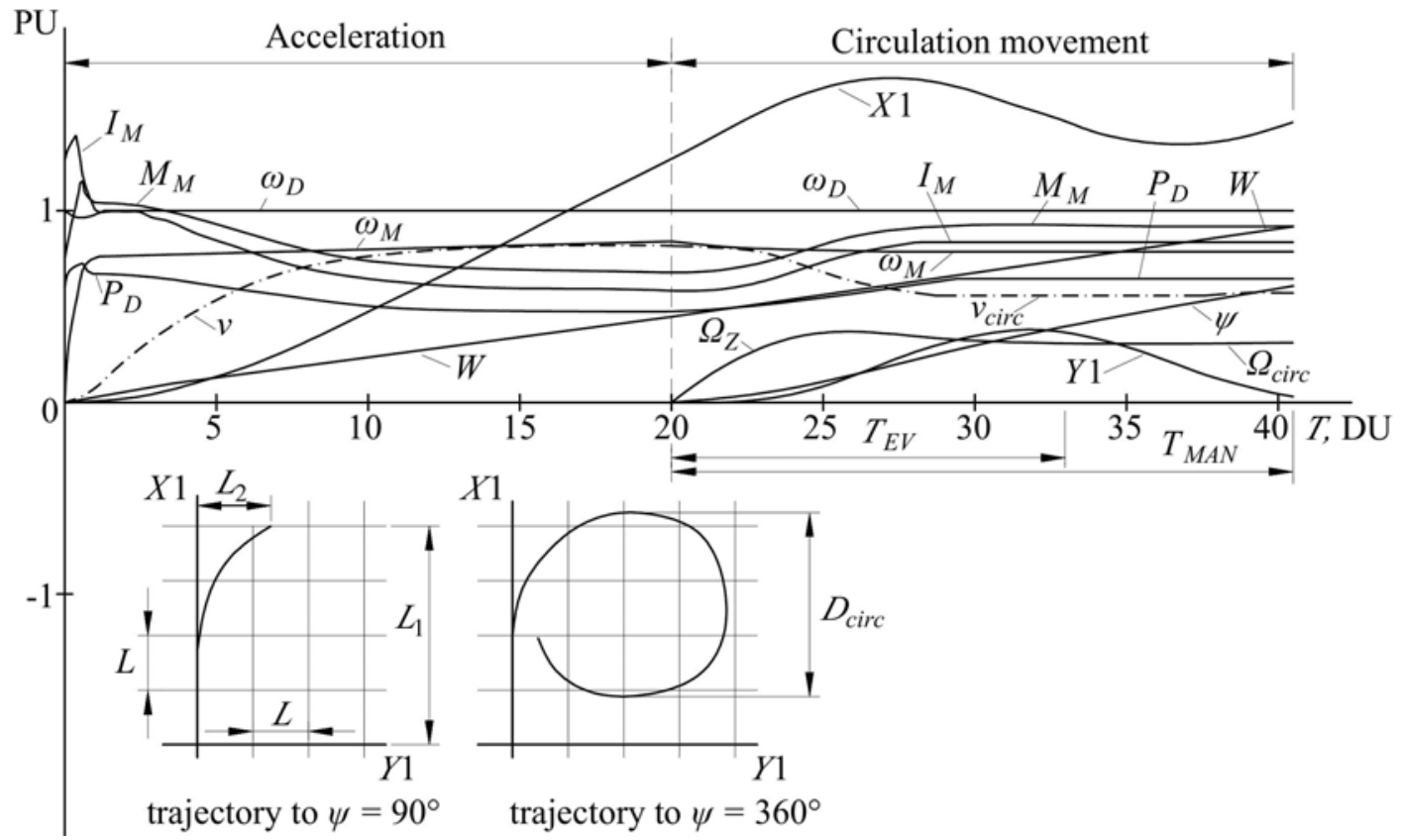

Fig. 3. The current values of the main performance indicators when performing the maneuver «acceleration of the EPP - exit to circulation»

Figure 3 shows the relative values of the operating parameters of the internal, most loaded, power circuit: heat engine $\left(\omega_{D}, P_{D}\right)$; propelling motor $\left(I_{M}, M_{M}, \omega_{M}\right)$. The current values are also given for: energy consumption $(W)$; speed of movement of the vessel $(v)$ and its course $(\psi)$; the path traveled by the electric ship $(X 1$ and $Y 1)$ in a coordinate system independent of the vessel, and the angular velocity $\left(\Omega_{\mathrm{Z}}\right)$ of its rotation around the vertical axis passing through the center of gravity of the vessel.

In the initial state, the vessel is stationary, the generating sets are idling. Acceleration begins with an increase in the relative values of $\alpha$ and $\gamma$ of the voltage supplying the electric motors. PMs begin to accelerate. The torque $M_{M}$ increases, and the rotational speeds of the 
motors and propellers $\omega_{M}$ increase accordingly. The thrust of the propellers increases, and the electric ship begins to accelerate (its speed $v$ increases). With an increase in the engine speed $\omega_{M}$ and the vessel's speed $v$, the propeller drag moment $M_{P}$ increases. As the supply voltage rises, the current $I_{M}$ and the torque $M_{M}$ of the electric motor increase. The load on the heat engine increases. Its power $P_{D}$ increases, and the rotational speed $\omega_{D}$, accordingly, slightly decreases. The energy consumption $W$ is increasing. The distance traveled by the ship increases. Gradually, after 12-13 relative units of time (in the described maneuver), the transient process ends, and the propulsive complex enters the operating mode close to the steady state. The distance traveled by the electric ship during the maneuver is described by the $X 1$ curve.

From the moment $T=20$ relative time units, the process of the ship entering a curvilinear trajectory begins. The loads on the propulsion motors and on the heat engines of the generating sets increase $\left(I_{M}, M_{M}, P_{D}\right.$ increase, $\omega_{M}$ decreases). The electric ship goes into circulation. The angular velocity $\Omega_{Z}$ and the lateral displacement $Y 1$ appear. The vessel's speed $v$ decreases. At approximately $T=33$ relative time units, the evolutionary period of the circulation movement ends and its quasi-steady period begins. The electric ship reaches the steady-state values of the speed of movement $v_{\text {circ }}$ and the angular speed of rotation (circulation) $\Omega_{\text {circ }}$. The maneuver ends when the ship reaches the course $\psi=360^{\circ}$ (full circulation). The total duration of the considered maneuver is $T=40.5$ relative time units. The trajectory of the electric ship's center of gravity is shown in Fig. 3.

The change in the current values of the performance indicators clearly demonstrates the nature of the course of transient processes. However, to assess the maneuvering characteristics of the complex, separate indicators of the quality of maneuvering operations are needed, which make it possible to assess the behaviour of both the components of the propelling electric power plant and the electric ship as a whole. These are: speed fluctuations and power fluctuations of heat engines; maximum values of currents and torques of synchronous generators and propelling motors in transient modes; indicators characterizing the stability of the parameters of the electricity of the ship's electrical network; inertial characteristics of the vessel; energy consumption (fuel consumption) for performing maneuvers. The mathematical model and the calculation method [10] allow to do this.

At electric ships, control of each power circuit of the propulsion electric power plant (control of each PM) is carried out independently of the others. Control signals are supplied to each propelling motor (by shifting the control post handles) - by the frequency of rotation of the PM (determined by the relative frequency of the current $\alpha$ ) and by voltage (determined by the value of $\gamma$ ). The control of the electric ship, when entering a curvilinear trajectory, is carried out by shifting the rudder blade to the starboard side, while simultaneously braking the right propelling motor. With such maneuvering, the angles of the bevel of the flow of water running on the outer and inner (relative to the center of circulation) propellers change significantly (Fig. 1). Their hydrodynamic characteristics change. The moments of resistance on the shaft of the propelling motors of the outer and inner circuits are different.

With such a maneuver, the relative frequency of the current $\alpha_{L}$ for the left PM is constant throughout the entire maneuver. For the right PM, the frequency $\alpha_{R}$ decreases with the beginning of maneuvering (in accordance with the new position of the control post handle) and remains unchanged until the end of the maneuver. The difference between $\alpha_{L}$ and $\alpha_{R}$ will be called the degree of braking of the propelling motor (propeller).

As noted above, the classical law of frequency control does not allow achieving high maneuverability of electric ships. With a systematic approach to the optimal control of the PM, it becomes necessary to search for such control signals that will provide the best values for the quality indicators of the maneuvering of electric ships. Here, it is imperative to monitor the performance of all components of the propulsion electric power plant, and first of all, the propulsion electric motors and drive motors of generator sets. form:

In [8], it was proposed to form control signals in the

$$
\begin{gathered}
\alpha=\alpha_{\text {prim }}+k_{1}\left(1-\exp \left(-k_{5} T\right)\right), \\
\gamma=k_{2} \alpha+k_{3} \alpha^{2}+k_{4} \alpha^{3}+\left(1-k_{2}-k_{3}-k_{4}\right) \alpha^{4},
\end{gathered}
$$

where: $\alpha_{\text {prim }}$ is the initial value of the relative frequency of the supply voltage of the PM; $k_{2}, k_{3}, k_{4}$ are the parameters of control signals that are being optimized.

For the considered maneuver, it makes no sense to optimize the dependence $\alpha=\alpha(T)$, since $\alpha$ is fixed and is determined by a given (by the control post handle) speed of the PM. Optimization will concern only the search for optimal parameters of the control law $\gamma / \alpha$.

According to this goal, either the minimum energy consumption for the execution of the maneuver $-W_{C \min }$, or the minimum run-out of the electric ship $-L_{1 \text { min }}$ are taken as optimality criteria. The first criterion characterizes the economic indicators of maneuvering, the second one - the safety of maneuvering operations.

In accordance with the task, it is necessary to minimize the objective function

$$
W(\boldsymbol{k}) \rightarrow \min , k \in \boldsymbol{k}^{n},
$$

or

$$
L_{1}(\boldsymbol{k}) \rightarrow \min , k \in \boldsymbol{k}^{n},
$$

where $\boldsymbol{k}=\left[k_{2}, k_{3}, k_{4}\right]$ are the parameters to be optimized; $\boldsymbol{k}^{n}$ is the admissible region of the $n$-dimensional space. Linear constraints $p$ in the form of inequalities $g_{j}(\boldsymbol{k}) \geq 0$, $j=1,2, \ldots, p$ are determined by the tolerances for the ranges of changes in the EPP performance indicators and other conditions for performing maneuvers.

In [8], a method for finding optimal solutions to such problems is described. It was developed based on the peculiarities of the object under consideration and the complex topography of the target functions revealed during the research. In the process of optimization, the calculations of the current values of all operating parameters of the complex are carried out during the execution of the corresponding maneuvers by the electric ship and, based on their results, the energy consumption for the execution of the maneuver and the run of the electric ship are determined. 
Results of work. Below are the results of optimization of the parameters of the frequency control law. The search for optimal parameters was carried out for one of the typical (described above) maneuvers of electric ships - acceleration and entry into circulation. Optimization was carried out according to the $W_{C \min }$ and $L_{1 \text { min }}$ criteria.

When generating control signals to propulsion motors, it is necessary, as noted above, to ensure the operation of the propulsion electric power plant in permissible modes. From Fig. 1 it can be seen that the internal propeller operates in a flow with a larger bevel angle. The load on its propeller motor turns out to be significantly greater than the load on the external PM. The possible actuation of the protection systems of the «internal» power circuit can lead to a failure to perform a maneuver or even to an emergency. Based on this, when searching for the optimal parameters of control signals, first of all, it is necessary to control the performance indicators of the internal power contour.

The nature of the maneuvering operations performed by the electric ships, and, accordingly, the fuel consumption and run-out of the electric ship, are influenced by the design parameters of the ship, and the parameters of the electric power plant and external conditions. The degree of influence of each parameter is different. When looking for optimal propulsion motor control, it is very important to cover as many electric ships as possible. In other words, the recommendations should be valid for a wide class of ships.

In the process of developing a mathematical model of transient modes (in relative units), criteria for dynamic similarity (generalized dimensionless parameters of propulsion complexes) were identified; the ranges of change of their values are found, covering all electric ships with frequency-controlled PM (with a traditional propeller drive).

As shown by preliminary studies (screening experiments), the following parameters have the most significant influence on the selected criteria, when maneuvering by the rudder and propeller motors together: the degree of braking; $v_{\text {prim }}$ - the initial speed of the vessel; $\beta_{R}$ - the rudder blade shift angle; generalized dimensionless parameter of the complex $N_{X}$ - power-toweight ratio of the electric ship

$$
N_{X}=\frac{L \sum K_{P j} P_{e j 0}}{\left(m+\lambda_{11}\right) v_{0}^{2}},
$$

where $P_{e j 0}$ and $K_{P j}$ are the effective stop of the propeller in the steady state and its share in the total stop, respectively; $m$ and $\lambda_{11}$ are the mass of the vessel and the masses of water attached to it (along the longitudinal axis $X$ ).

For various ratios between these parameters (in fact, for various electric ships), optimization calculations were carried out and optimal solutions were obtained. As an example, in Table 1 (according to the criterion of minimum energy consumption $W_{C \min }$ ) and in Table 2 (according to the criterion of minimum ship run-out $L_{1 \mathrm{~min}}$ ) some of their results are given. These are the optimal parameters of the frequency control law $\gamma / \alpha$, presented in the form of equation (5), when the vessel enters circulation with simultaneous rotation of the rudder blade $\beta_{R}$ and braking of the right propelling motor. The calculations were carried out for maneuvers at the relative initial speed of the vessel $v_{\text {prim }}=1.0$ and $v_{\text {prim }}=0.8$. Table 1 shows a small number of options for combinations of $\alpha_{L}, \alpha_{R}, N_{X}, \beta_{R}$ and optimal solutions for performing the maneuver by the criterion of minimum $W_{C \text { min }}$.

Table 1

Combinations of significant parameters and optimal solutions for the criterion of minimum energy consumption $W_{C \min }$

\begin{tabular}{|c|c|c|c|c|c|c|c|c|c|c|c|}
\hline \multirow{3}{*}{ Option } & \multicolumn{5}{|c|}{ Numerical values of parameters, p.u. } & \multirow{3}{*}{$\begin{array}{c}W_{\text {Cclassic }} \\
\text { p.u. }\end{array}$} & \multicolumn{4}{|c|}{ Optimal solutions } & \multirow{3}{*}{$\begin{array}{c}\text { Efficiency, } \\
\%\end{array}$} \\
\hline & \multirow{2}{*}{$v_{\text {prim }}$} & \multirow{2}{*}{$\alpha_{L}$} & \multirow{2}{*}{$\alpha_{R}$} & \multirow{2}{*}{$N_{X}$} & \multirow{2}{*}{$\beta_{R}$} & & \multicolumn{3}{|c|}{ equation $\gamma=\gamma(\alpha)$} & \multirow{2}{*}{$\begin{array}{c}W_{C \min }, \\
\text { p.u. }\end{array}$} & \\
\hline & & & & & & & $k_{2}$ & $k_{3}$ & $k_{4}$ & & \\
\hline 1 & 1,0 & 1,0 & 0,8 & 0,12 & 0,262 & 16,67 & 2,08 & $-1,15$ & 2,38 & 15,37 & 7,8 \\
\hline 2 & 0,8 & 0,8 & 0,65 & 0,12 & 0,262 & 15,09 & 2,97 & $-2,39$ & 1,71 & 10,86 & 28,03 \\
\hline 3 & 0,8 & 0,8 & 0,55 & 0,12 & 0,262 & 13,16 & 3,24 & $-2,62$ & 1,16 & 9,352 & 28,94 \\
\hline$\cdots$ & $\cdots$ & $\cdots$ & $\ldots$ & $\cdots$ & $\cdots$ & $\cdots$ & $\cdots$ & $\cdots$ & $\cdots$ & $\cdots$ & $\cdots$ \\
\hline 14 & 0,8 & 0,8 & 0,65 & 0,165 & 0,4 & 11,0 & 3,47 & $-3,089$ & 1,342 & 7,93 & 27,91 \\
\hline 15 & 0,8 & 0,8 & 0,55 & 0,165 & 0,4 & 9,7 & 3,27 & $-2,67$ & 1,21 & 6,88 & 29,07 \\
\hline$\cdots$ & $\cdots$ & $\cdots$ & $\cdots$ & $\cdots$ & $\cdots$ & $\cdots$ & $\cdots$ & $\cdots$ & $\cdots$ & $\cdots$ & $\cdots$ \\
\hline 25 & 1,0 & 1,0 & 0,8 & 0,21 & 0,576 & 9,95 & 2,73 & $-0,07$ & $-2,66$ & 9,13 & 8,2 \\
\hline 26 & 0,8 & 0,8 & 0,65 & 0,21 & 0,576 & 9,09 & 2,56 & 0,08 & $-2,27$ & 6,93 & 27,51 \\
\hline 27 & 0,8 & 0,8 & 0,55 & 0,21 & 0,576 & 8,02 & 3,2 & $-2,57$ & 1,26 & 5,71 & 28,8 \\
\hline
\end{tabular}

In Fig. 4, as an illustration, graphical interpretations of the control signal (5) are given with the optimal values of the coefficients $k_{2}, k_{3}, k_{4}$ for the first three options (from Table 1) combinations of parameters $\alpha_{L}, \alpha_{R}, N_{X}, \beta_{R}$ are presented.
To assess the effectiveness of optimization, the corresponding maneuvers were calculated when controlling the propulsion electric motors and according to the classical proportional law. The results of calculating the energy consumption for performing 
maneuvers according to this law are given in the $W_{\text {Cclassic }}$ column of the Table 1. The last column of the table illustrates the efficiency of optimization - the degree to which energy costs are reduced when switching to optimal control. Depending on the conditions of maneuvering, it ranges from $8 \%$ to $29 \%$.

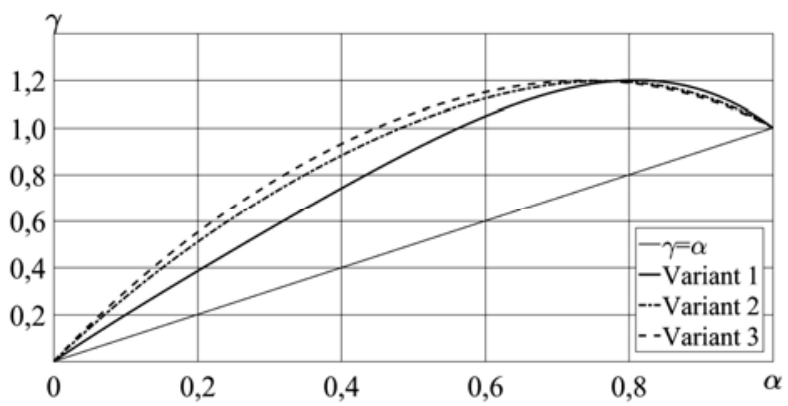

Fig. 4. Dependencies $\gamma=\gamma(\alpha)$ according to the criterion of minimum energy consumption $W_{C \min }$

A lower degree of efficiency corresponds to the movement of the vessel at a higher speed, and a higher efficiency - when moving at a lower speed and maximum braking by the propelling motor (it should be borne in mind that the degree of braking is limited by the hydrodynamic characteristics of the propeller). Thus, the transition to optimal control of the PM (and the joint maneuvering by the motors and the rudder is most often carried out precisely at the partial motion of the vessel) significantly reduces the energy consumption $W_{C}$ for the maneuver, which confirms its expediency.

Change in the optimality criterion leads, as expected, to other optimal solutions. Table 2 shows the results of optimization calculations according to the criterion of minimum run-out of the electric ship $L_{1 \min }$ when it enters circulation. As can be seen from the table, the numerical values of the coefficients $k_{2}, k_{3}$ and $k_{4}$ differ significantly from those obtained by the criterion of the minimum energy consumption.

Figure 5 shows graphical interpretations of control signals with optimal values of the coefficients $k_{2}, k_{3}, k_{4}$ for the same first three (as in Table 1) options for parameters $\alpha_{L}, \alpha_{R}, N_{X}, \beta_{R}$ combinations.

Table 2

Combinations of significant parameters and optimal solutions for the criterion of minimum run-out of the electric ship $L_{1 \mathrm{~min}}$

\begin{tabular}{|c|c|c|c|c|c|c|c|c|c|c|c|}
\hline \multirow{3}{*}{ Option } & \multicolumn{5}{|c|}{ Numerical values of parameters, p.u. } & \multirow{3}{*}{$\begin{array}{l}L_{1 \text { classic }} \\
\quad \text { p.u. }\end{array}$} & \multicolumn{4}{|c|}{ Optimal solutions } & \multirow{3}{*}{$\begin{array}{c}\text { Efficiency } \\
\%\end{array}$} \\
\hline & \multirow{2}{*}{$v_{\text {prim }}$} & \multirow{2}{*}{$\alpha_{L}$} & \multirow{2}{*}{$\alpha_{R}$} & \multirow{2}{*}{$N_{X}$} & \multirow{2}{*}{$\beta_{R}$} & & \multicolumn{3}{|c|}{ equation $\gamma=\gamma(\alpha)$} & \multirow{2}{*}{$\begin{array}{l}L_{1 \min }, \\
\text { p.u. }\end{array}$} & \\
\hline & & & & & & & $k_{2}$ & $k_{3}$ & $k_{4}$ & & \\
\hline 1 & 1,0 & 1,0 & 0,8 & 0,12 & 0,262 & 7,03 & 3,32 & $-7,58$ & 2,33 & 6,62 & 5,8 \\
\hline 2 & 0,8 & 0,8 & 0,65 & 0,12 & 0,262 & 6,28 & 3,54 & $-7,96$ & 3,55 & 5,62 & 10,5 \\
\hline 3 & 0,8 & 0,8 & 0,55 & 0,12 & 0,262 & 5,8 & 3,8 & $-8,6$ & 2,1 & 5,36 & 7,6 \\
\hline$\ldots$ & $\ldots$ & $\ldots$ & $\ldots$ & $\ldots$ & $\ldots$ & $\ldots$ & $\ldots$ & $\ldots$ & $\ldots$ & $\ldots$ & $\ldots$ \\
\hline 17 & 0,8 & 0,8 & 0,65 & 0,21 & 0,4 & 4,9 & 3,51 & $-7,9$ & 2,2 & 4,56 & 6,9 \\
\hline$\ldots$ & $\ldots$ & $\ldots$ & $\ldots$ & $\ldots$ & $\ldots$ & $\ldots$ & $\ldots$ & $\ldots$ & $\ldots$ & $\ldots$ & $\ldots$ \\
\hline 25 & 1,0 & 1,0 & 0,8 & 0,21 & 0,576 & 4,15 & 3,57 & $-8,23$ & 2,27 & 3,94 & 4,6 \\
\hline 26 & 0,8 & 0,8 & 0,65 & 0,21 & 0,576 & 4,137 & 3,72 & $-8,57$ & 2,05 & 3,85 & 9,7 \\
\hline 27 & 0,8 & 0,8 & 0,55 & 0,21 & 0,576 & 4,06 & 3,87 & $-8,79$ & 2,01 & 3,72 & 8,3 \\
\hline
\end{tabular}

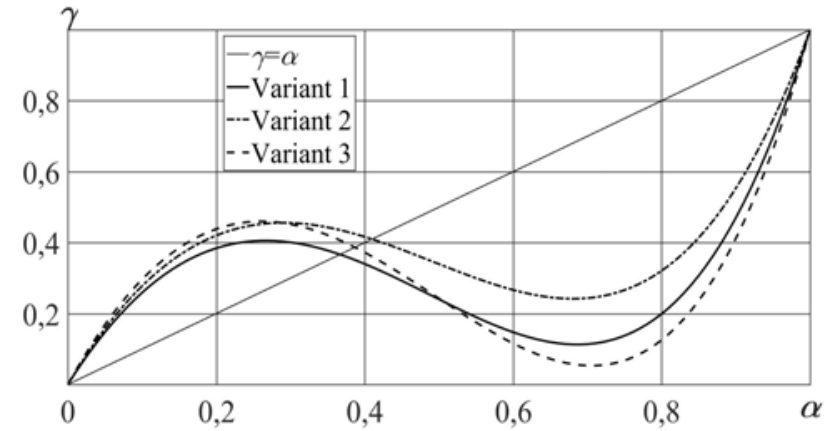

Fig. 5. Dependencies $\gamma=\gamma(\alpha)$ according to the criterion of minimum run-out of the electric ship $L_{1 \min }$

Analysis of these dependencies shows the following. Since, simultaneously with the rudder blade shifting, the braking of the right propeller motor is performed, the loads on this PM increase. In addition, the internal PM propeller begins to operate in a water flow with a larger bevel angle (Fig. 1), which leads to an increase in its drag moment.
This does not affect the operating performance of the generating sets, since they are covered by cross-links, and this is reflected in the performance of propulsion electric motors, since their power circuits are independent of each other. Internal PMs are loaded more and their performance indicators can approach the setpoints for the operation of protection systems.

To prevent the emergency shutdown of the PM (such maneuvers are carried out, as a rule, in order to prevent collision of ships), it is necessary to reduce the voltage value, which should be done by the automatic control system in accordance with the calculated optimal laws. This can be seen in Fig. 5.

To evaluate the efficiency of optimization (as for the $W_{\text {Cclassic }}$ option in Table 1), Table 2 shows the results of calculating the run-out of an electric ship when controlling propeller motors also according to the classical proportional law. The results of calculations according to this law are given in the $L_{1 \text { classic }}$ column. The efficiency of optimization - the degree of decrease in the run-out of the electric ship varies depending on the 
conditions of maneuvering from $5 \%$ to $11 \%$. As in the previous case, a greater degree of efficiency is obtained when the vessel is moving at intermediate speeds.

To illustrate the behaviour of the propulsive complex after optimization of control laws, Fig. 6 shows the current values of the main performance indicators when performing the same maneuver as in Fig. 3. This is option No. 27 of a combination of significant parameters and conditions for performing the maneuver (Table 2) The selected option is an example of average efficiency.

Comparative analysis of the calculation results shows that with the transition to optimal control, the run of the electric ship (the criterion of optimality) decreased from 4.06 to 3.72 of the length of the vessel, which is 8.3 $\%$. The numerical values of the main performance indicators when controlling according to proportional and optimal laws are also given in Table 3.

Thus, the transition to optimal control of the PM can significantly reduce the run-out of the electric ship, which contributes to the increase in the safety of maneuvering operations.

Discussion. The studies carried out clearly show that the traditional control of propelling electric motors does not allow to fully realize the high maneuverability inherent in electric ships.

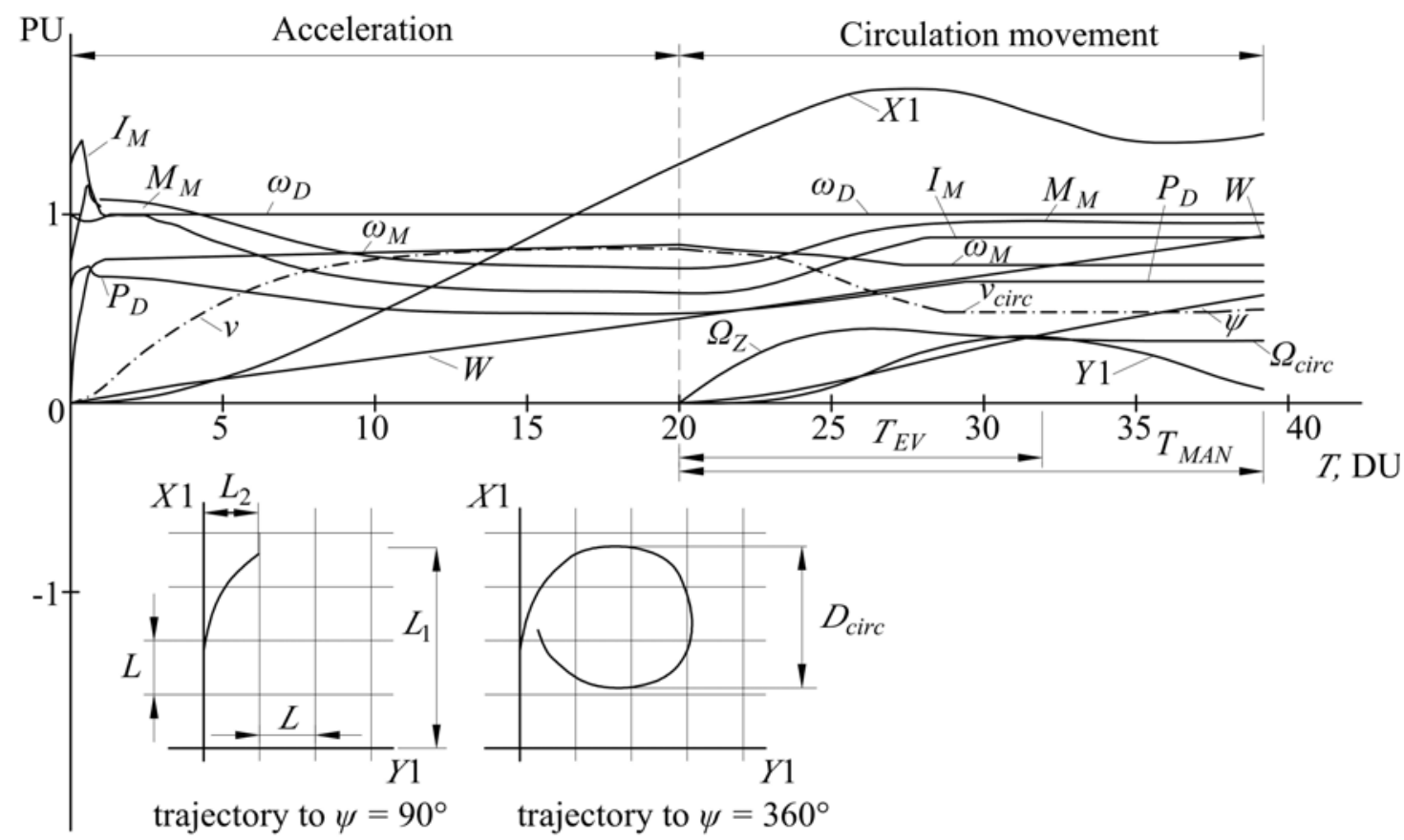

Fig. 6. Current values of the main operating parameters of the maneuver «acceleration of the EPP - exit to circulation» under optimal control low

Table 3 indicators of the ship's operation, in particular, its best Indicators of the quality of maneuvering under different control laws

\begin{tabular}{|c|c|c|c|}
\hline $\begin{array}{c}\text { Quality } \\
\text { indicator }\end{array}$ & Proportional low & Optimal low & $\begin{array}{c}\text { Indicator } \\
\text { deviation, \% }\end{array}$ \\
\hline$T_{M A N}$ & 20,5 & 19,2 & $+6,3$ \\
\hline$T_{E V}$ & 13 & 11,9 & $+8,4$ \\
\hline$W$ & 23,5 & 22 & $+6,8$ \\
\hline$L_{1}$ & $4,06 L$ & $3,72 L$ & $+8,3$ \\
\hline$L_{2}\left(\psi=90^{\circ}\right)$ & $1,32 L$ & $0,98 L$ & $+25,8$ \\
\hline$D_{\text {circ }}$ & $3,22 L$ & $2,63 L$ & $+18,3$ \\
\hline$I_{M}$ & 0,83 & 0,88 & -6 \\
\hline$M_{M}$ & 0,92 & 0,96 & $-4,3$ \\
\hline$\omega_{M}$ & 0,79 & 0,73 & $-7,6$ \\
\hline$v_{\text {circ }}$ & 0,56 & 0,48 & $-14,3$ \\
\hline
\end{tabular}
maneuverability and high economic performance. We need a systematic approach to control the PM during maneuvers. In this case, «electrical» indicators should recede into the background. It is necessary to find such a control that will provide the best performance of the electric ship, with the controlled performance of its propeller electric power plant.

The solution of such problems is possible only with an integrated approach. The propeller electric power plant should be considered together with all the components of a single ship propulsion complex, which includes, in addition to the EPP, also propellers, a rudder and a hull of the ship. The presence of a mathematical model describing the behavior of the propulsive complex during maneuvers, a method for calculating the current values of the main performance indicators, and a correct (suitable for solving such problems) optimization method allows achieving this goal.

As shown in this work, with the correct organization law, obtained in relation to the «electrical» indicators of the quality of electric motors, does not take into account the performance of the vessel. But propelling electric motors are designed precisely to ensure the best quality of the propulsion electric motors control, it is possible to achieve the best values of the quality indicators of maneuvers and ensure, at the same time, the operation of 
all the components of the propulsion electric power plant in permissible modes.

\section{Conclusions.}

1. The expediency of using a systematic approach in the search for optimal control of propelling electric motors of electric ships when maneuvering on a curvilinear trajectory has been substantiated. As the main criteria of optimality indicators ones characterizing the maneuverability of the vessel should be taken. The performance indicators of the EPP should be considered as constraints.

2. The disadvantages of the «classical» version of the EPP control have been grounded. A method is proposed for generating control signals for the EPP, with a simultaneous shift of the rudder blade, when the vessel enters circulation. A procedure for optimizing the parameters of control signals has been developed.

3. Optimization calculations were carried out and the optimal parameters of control signals for propelling motors were found. Optimization was carried out according to the criterion of the minimum energy consumption for performing the maneuver and according to the criterion of the minimum run-out of the electric ship. Optimization efficiency ranges from $5 \%$ to $29 \%$.

\section{REFERENCES}

1. Molland A. The maritime engineering reference book. A guide to ship design, construction and operation. ButterworthHeinemann, Oxford, UK, 2008. 920 p. doi: doi:10.1016/b9780-7506-8987-8.x0001-7.

2. Bertram V. Practical Ship Hydrodynamics. ButterworthHeinemann, Oxford, UK, 2012. 390 p. doi: 10.1016/C2010-068326-X.

3. Carlton J.S. Marine propellers and propulsion. 4th edition. Butterworth-Heinemann, Oxford, UK, 2018. 609 p. doi: 10.1016/C2014-0-01177-X.
4. Nebesnov V.I. Engine dynamics in the ship hull-propellerengine system. Leningrad, Sudpromgiz Publ., 1961. 374 p. (Rus).

5. Leonhard W. Control of electrical drives. Springer-Verlag Berlin Heidelberg, 2001. 241 p. doi: 10.1007/978-3-642-56649-3.

6. Bose B.K. Power electronics and AC drives. Prentice Hall, Englewood Cliffs, New York, 2001. 738 p.

7. Mohan N., Undeland T.M., Robbins W.P. Power electronics, converters, applications and design. J. Wiley, New York, 2003. $811 \mathrm{p}$.

8. Yarovenko V.A., Chernikov P.S., Varbanets R.A., Zaritskaya E.I. Optimal control of the electric ships' propulsion motors during reversal. Electrical engineering \& electromechanics, 2018, no. 6, pp. 38-46. doi: 10.20998/2074272X.2018.6.05.

9. Chernikov P.S., Yarovenko V.A., Zaritskaya E.I. The influence of control laws of frequency-regulated electric motors on electric ships' maneuvering characteristics. Bulletin of NTU «KhPI». Series: "Electric machines and electromechanical energy conversion», 2020, no. 3 (1357), pp. 45-51. (Ukr). doi: 10.20998/2409-9295.2020.3.08.

10. Yarovenko V.A., Chernikov P.S. A calculation method of transient modes of electric ships' propelling electric plants. Electrical engineering \& electromechanics, 2017, no. 6, pp. 32-41. doi: 10.20998/2074-272X.2017.6.05.

Received 25.07.2020

V.A. Yarovenko ${ }^{1}$, Doctor of Technical Science, Professor,

P.S. Chernikov ${ }^{1}$, Candidate of Technical Science,

E.I. Zaritskaya ${ }^{1}$, Candidate of Technical Science, Associate Professor,

A.N. Schumylo ${ }^{1}$, Candidate of Technical Science, Associate

Professor,

${ }^{1}$ Odessa National Maritime University,

34, Mechnikova Str., Odessa, 65007, Ukraine,

e-mail: yarovenko@3g.ua, chernikov@onmu.odessa.ua,

zarickayalena@ukr.net, shumilo.alexander@gmail.com

How to cite this article:

Yarovenko V.A., Chernikov P.S., Zaritskaya E.I., Schumylo A.N. Control of electric ships' propulsion motors when moving on curvilinear trajectory. Electrical engineering \& electromechanics, 2020, no. 5, pp. 58-65. doi: 10.20998/2074-272X.2020.5.09. 